\title{
Performance Analysis of IMB (Building Permit) Licensing Services in the Capital Investment Service and Integrated Service of One Door and Labor of Pekalongan Regency
}

\author{
Aufarul Marom \\ \{maromsemarang@gmail.com\} \\ Universitas Diponegoro, Indonesia
}

\begin{abstract}
This study aims to analyze the performance achievements of the IMB licensing service at the DPMPTSP and Naker and any factors that hinder and encourage the successful achievement of its performance. Residents who will build the building are required to have a building permit (IMB). The existence of the IMB aims to create a building layout that is safe and in accordance with the allotment of land as well as to ensure the clarity of the existence of the building or the legality of the building, so that the building owner can get legal protection. In DPMPTSP and Naker in Pekalongan Regency in 2019, among 2742 Non-Business licensing matters, 2251 (82.09\%) of which were IMB licensing arrangements. This large portion of the IMB licensing sector requires optimal performance from the apparatus that handles it so that the community can be well served. Aspects to be studied include Vision and Mission, employee empowerment, flexibility and adaptation to new conditions, communication with related parties regarding organizational performance, determining the results to be achieved and focusing on achieving success, and competition to improve performance.
\end{abstract}

Keywords: Performance Analysis, Licensing Services, IMB

\section{Introduction}

Basically, everyone is allowed to do whatever they want except something that requires permission so as not to disturb others so that it is in accordance with the policies and arrangements made by the government. Likewise, residents who are going to build a building are required to have an IMB (Building Permit). The existence of the IMB aims to create a building layout that is safe and in accordance with the designation of the land as well as to ensure clarity of the existence of the building or the legality of the building. By having an IMB, home or building owners can get maximum legal protection. That way when the building stands, it will not interfere or harm the interests of others.

In DPMPTSP and Naker (Investment Service and One Stop Integrated Service and Manpower) of Pekalongan Regency in 2019, among 2742 non-business licensing affairs, 2251 of which were processing IMB permits, $82.09 \%$ of which were IMB matters. The large portion of the permit in the IMB sector demands optimal performance from the officials who handle it so that the community can be served properly. 
Table 1. Processing IMB Permit

\begin{tabular}{|c|c|c|}
\hline No & Year & IMB Permit \\
\hline 1. & 2017 & 487 \\
\hline 2. & 2018 & 1.519 \\
\hline 3. & 2019 & 2.251 \\
\hline
\end{tabular}

Source: Dinas DPMPTSP and Naker Pekalongan Regency.

Table 1 shows that the IMB permit that has been successfully processed by DPMPTSP and Naker in Pekalongan Regency shows a significant increase in the last three years. In 2017, 487 IMB successfully processed increased sharply to 1.519 in 2018 , and even increased to 2.251 in 2019.

Based on the Regulation of the Regent of Pekalongan Number 61 of 2018 concerning Building Permits, the time period for the application process and the issuance of the IMB as referred to in Article 20 letter $\mathrm{c}$ is calculated since the submission of the IMB application is declared complete, includes:

a. Examination and assessment of requirements and determination of retribution as referred to in Article 33 paragraph (1) letter a and paragraph (2), no later than 30 (thirty) working days from the receipt of IMB application which is declared technically and administratively complete; and

b. Issuance of the IMB no later than 7 (seven) working days from the receipt of proof of payment of the IMB retribution.

On the basis of the Regent Regulation as mentioned above, it is interesting to examine to what extent the performance of DPMPTSP and Naker in providing IMB licensing services to the people of Pekalongan Regency. Can the time limit determined and regulated by the Regent Regulation be demonstrated through the performance of the agencies in charge of it, namely DPMPTSP and Naker Pekalongan Regency?

\section{Method}

The type of research used by researchers is descriptive qualitative research type, which is to describe and analyze the performance of IMB licensing services in DPMPTSP and Naker Pekalongan Regency As for those who are research subjects or as resource persons and are also referred to as informants in the study with the title IMB Licensing Service Performance Analysis (Building Permit) At the One Stop Investment and Integrated Service and Manpower Office of Pekalongan Regency are several officers and officials who handle IMB licensing at DPMPTSP and Naker Pekalongan Regency.

\section{Results and Discussion}

\subsection{Definition of Performance}

The concept of performance is an attempt to state the ability of a person or organization to achieve certain goals or objectives. Performance is the result of work that has a strong relationship with organizational strategic objectives, customer satisfaction, and contributes to 
the economy [1]. Thus, performance will be related to doing work and the results achieved from that work. Performance is related to what is done and how to do it.

According to Mangkunegara [2]: "Performance (work performance) is the result of work in quality and quantity achieved by an employee in carrying out his duties in accordance with the responsibilities given to him".

The term performance is often interpreted as appearance, work results or achievement. In the Illustrated Oxford Dictionary, this term denotes "the execution or fulfillment of a duty" (implementation or achievement of a task). Meanwhile, the notion of performance is often defined as performance, work results or work performance. Performance has a broader meaning, not only as a result of work, but also how the work process takes place. Performance will relate to how to do work and the results achieved from that work.

Hasibuan [3] argues that: "Performance (work performance) is a result of work achieved by a person in carrying out the tasks assigned to him based on skill, experience and seriousness and time".

The performance of individuals and organizations / institutions / institutions describes the extent to which a person or institution has carried out their duties so that they can provide the results determined by the group or institution. Performance is carrying out an activity and perfecting it according to its responsibilities with results as expected. It can be concluded that the definition of performance is a work result that can be achieved by a person or group of people in an organization, in accordance with their respective authorities and responsibilities, in order to achieve organizational goals, does not violate the law, and is in accordance with morals and ethics. Performance is a description of the level of achievement of the implementation of an activity/program/policy in realizing the goals, objectives, mission and vision of the organization. Basically, the definition of performance relates to the responsibility of an individual or organization in carrying out what is the authority and responsibility given to him.

\subsection{Organizational Performance Analysis Indicators}

In Keban [4] it is stated that in general the parameters and criteria used in assessing performance include (1) quality, (2) quantity, (3) timeliness, (4) cost savings, (5) independence and autonomy at work, (6) cooperation.

According to Schuler and Dowling [5], performance can be measured from (1) quantity of work, (2) quality of work, (3) cooperation (4) knowledge of work (5) independence of work, (6) attendance and timeliness (7) knowledge of policies and organizational goals (8) healthy initiatives and ideas (9) supervisory and technical capabilities.

\subsection{Performance Measurement Methods}

According to Sudiman [6] to conduct an analysis of organizational performance it is necessary to determine the indicators to be measured. This indicator can be broken down by a combination of approaches to achieving goals, systems / internal process approaches, strategic constituent satisfaction approaches, competing factors approaches, etc. In addition, indicators can also be seen from several well-known performance measurement methods such as the Common Assessment Framework (CAF) and the Baldrige National Quality Program (BNQP).

The Common Assessment Framework (CAF) is a tool for measuring organization (selfassessment) in the public sector. CAF was developed by the Director General of Public Administration from member countries of the European Union to support the introduction of ideas and principles of Total Quality Management (TQM) in the public sector in the European 
Union and beyond. The CAF consists of 9 evaluation criteria which together form a logical, comprehensive framework and allow for measurement of the activities and relevant actions and performance of public sector organizations. Four criteria are used to measure enabler performance (what the organization does to achieve excellent results). Then five criteria are used to measure the results (the results achieved by the organization.

The criteria that fall into the enabler category are:

a. Criterion 1 Leadership;

b. Criterion 2 Policies and Strategies;

c. Criterion 3 HRM;

d. Criterion 4 Sources and External Partnerships. The criteria that fall into the results category are:

a. Criterion 5 Process and Change Management;

b. Criterion 6 Results Oriented to Service Users / Community;

c. Criterion 7 Human Results (Employee);

d. Criterion 8 Impact on Society;

e. Criterion 9 Key Performance Results.

The Baldrige National Quality Program (BNQP) is a program implemented by the National Institute of Standards and Technology (NIST), a Federal agency under the Commerce Department's Technology Administration. This program is aimed at increasing the level of competition, quality, productivity, and performance of organizations in the United States. The criteria evaluated through this method are built based on a set of values and concepts that are interrelated as follows:
a. Visionary Leadership;
b. Customer Driven Excellence;
c. Organizational and Personal Learning;
d. Valuing Employees and Partners;
e. Ability;
f. Focus on the Future;
g. Managing for Innovation;
h. Management by Fact;
i. Public Responsibility and Citizenship;
j. Focus on Results and Creating Value;
k. System Perspective.

Furthermore Sudiman [6] states that organizations that have high performance have 8 characteristics, including:

a. Have a clear mission;

b. Define the results to be achieved and focus on achieving those successes;

c. Empowering employees;

d. Motivate individuals in the organization to achieve success;

e. Are flexible and can always adapt to new conditions;

f. Always compete to improve performance;

g. Always perfect work procedures in order to meet the needs of customers or society;

h. Always communicate with stakeholders (parties related to organizational performance). 


\subsection{Relationship of Performance Indicators with High Performance Organizations}

Furthermore, if a red thread is drawn from the organizational performance indicators with the characteristics of a high-performance organization, there are almost similarities between the three. For more details, it can be seen in Table 2 .

Table 2. Organizational Performance Indicators and Characteristics of High Performing Organizations

\begin{tabular}{|c|c|c|c|}
\hline \multirow{2}{*}{ No. } & \multicolumn{2}{|c|}{ Performance Indicators } & \multirow{2}{*}{$\begin{array}{c}\text { High Performing Organization } \\
\text { Characteristics }\end{array}$} \\
\hline & CAF & BNQP & \\
\hline 1 & Leadership & \multirow{2}{*}{$\begin{array}{l}\text { - Visionary Leadership } \\
\text { - Focus on the Future }\end{array}$} & \multirow[b]{2}{*}{ Have a clear mission } \\
\hline 2 & $\begin{array}{l}\text { Policies and } \\
\text { Strategies }\end{array}$ & & \\
\hline 3 & HRD & $\begin{array}{l}\text { Valuing Employees and } \\
\text { Partners }\end{array}$ & Valuing Employees and Partners \\
\hline 4 & $\begin{array}{l}\text { Process and } \\
\text { Change } \\
\text { Management }\end{array}$ & $\begin{array}{l}\text { - Organizational and } \\
\text { Personal Learning } \\
\text { - Ability } \\
\text { - Managing for } \\
\text { Innovation } \\
\end{array}$ & $\begin{array}{l}\text { Being flexible and always able to } \\
\text { adapt to new conditions }\end{array}$ \\
\hline 5 & $\begin{array}{l}\text { Sources and } \\
\text { External } \\
\text { Partnerships }\end{array}$ & System Perspective & $\begin{array}{l}\text { Always communicate with } \\
\text { stakeholders (parties related to } \\
\text { organizational performance) }\end{array}$ \\
\hline 6 & $\begin{array}{l}\text { Outcomes Oriented } \\
\text { to Service Users / } \\
\text { Community }\end{array}$ & $\begin{array}{l}\text { - Customer Driven } \\
\text { Excellence } \\
\text { - Focus on Results and } \\
\text { Creating Value } \\
\end{array}$ & \\
\hline 7 & $\begin{array}{l}\text { Human (Employee } \\
\text { Results) }\end{array}$ & $\begin{array}{l}\text { Focus on Results and } \\
\text { Creating Value }\end{array}$ & $\begin{array}{l}\text { - Define the results to be } \\
\text { achieved and focus on } \\
\text { achieving those successes } \\
\text { - Empower employees } \\
\text { - Motivate individuals in the } \\
\text { organization to achieve success }\end{array}$ \\
\hline 8 & Impact on Society & $\begin{array}{l}\text { Public Responsibility } \\
\text { and Citizenship }\end{array}$ & $\begin{array}{l}\text { Always improve work } \\
\text { procedures to meet the needs of } \\
\text { customers or society }\end{array}$ \\
\hline 9 & $\begin{array}{l}\text { Key Performance } \\
\text { Results }\end{array}$ & $\begin{array}{l}\text { - Management by Fact } \\
\text { - Focus on Results and } \\
\text { Creating Value }\end{array}$ & $\begin{array}{l}\text { Always competing to improve } \\
\text { performance }\end{array}$ \\
\hline
\end{tabular}

Source: Sudiman [6].

With the approaches and indicators mentioned above to analyze organizational performance, these indicators can be used:

a. Vision and Mission;

b. Employee empowerment;

c. Flexible and adapt to new conditions; 
d. Always communicate with stakeholders/parties related to organizational performance (customer driven excellence);

e. Determining the results to be achieved and focusing on achieving these successes (focus on results and creating value);

f. Always compete to improve performance.

The results showed that in fact the Pekalongan District DPMPTSP and Naker Office had no target in carrying out the main tasks and functions of how many licensing services had been provided. If there is a target, it is usually in the form of fees that can be donated to regional income. The levies attached to DPMPTSP and Naker. In fact, according to the Ministerial Regulation, DPMPTSP is not targeted for retribution. Every year thousands of applications for IMB permits have been fulfilled.

The types of IMB permits include housing, shops, business premises (super market), etc. The requirements required for each are also different. For the IMB for the place of business, there must be an environmental permit, because the impact on the environment will be assessed. Later, the Department of Environment will determine how much it will affect the environment. If the effect is small, a SPPL (Surat Pernyataan Kesanggupan Pengelolaan dan Pemantauan Lingkungan Hidup/Statement of Ability to Manage and Monitor the Environment) from the Environmental Service will be issued which is a prayer requirement for IMB management.

The problem of obtaining an IMB is usually related to regulations, IMB matters are in the Ministry of Public Works and Public Housing at the Regency level since 2017, matters related to the IMB have been transferred to the Settlement Service. In the Ministry of Public Works, but below it at the Regency level, it is not the Public Works Office but the Settlement Service, the division in charge of the IMB goes to the Settlement Service.

From the applicant's point of view, the requirements often become obstacles because they involve two agencies. It should have been in the Public Works Office, but in reality, it involved the Settlement Service, so it involved two rooms, which should have only one room, because regulations made management require two rooms. At DPMPTSP and Naker Pekalongan District cannot use SIMBG (Sistem Informasi Manajemen Bangunan Gedung/Building Management Information System) suggested by the Ministry.

The period of time for IMB management if the requirements are complete can actually be completed in 5 days per unit or per permit, the problem is because the requirements are not yet complete. Usually, the problem is the housing permit, from the developer submitting one application, in which there are how many units.

The philosophy of the issuance of the IMB is that the building conforms to its best practices besides the land use so as not to violate the land designation in accordance with the RTRW (Rencana Tata Ruang Wilayah/Regional Spatial Plan) also so as not to violate the KRK (Keterangan Rencana Kota/City Plan Information) whether the land is for green areas (agriculture) for road boundaries etc.

Employee empowerment to achieve good performance has been carried out by DPMPTSP and Naker. If there is training, DPMPTSP Pekalongan will send a delegation to the Central BKPM. Training from the Central BKPM can be ensured every year always holding training, whereas if from the ministry sometimes there is sometimes none. The training delivery model usually uses a turn. What is gained during training really supports the implementation of work tasks, the most recent knowledge gained from training is OSS (One Stop Service).

The performance of DPMPTSP and Naker in Pekalongan Regency has been carried out well, the driving factor is due to technical factors that play a role and contribute to support.

When viewed from the public awareness in taking care of the IMB personally is still lacking. The IMB applicant is because they need to fulfill the requirements, like the KTP, if not 
as a condition to take care of something, people are also reluctant to apply for the KTP. Likewise, with the IMB.

Meanwhile, stakeholders as partners of DPMPTSP and Naker of Pekalongan Regency in IMB affairs are the Public Works and Spatial Planning Office and the Department of Settlements and the Environment, Communication with the Public Works and Settlement Services is usually through coordination meetings, sometimes also visiting related offices or communication by telephone. Discussions with stakeholders, usually about time, about when the necessary requirements are completed.

What usually happens is that the community misperceptions about the permits they are taking care of, they know that they have submitted the files to the DPMPTSP Office as the licensing agency knows it is done, even though there is the Public Works and Spatial Planning Office there is also the Settlement and Environment Service which sometimes requires certain requirements. This is what sometimes makes it difficult or the process for issuing building permits to be issued takes longer.

To solve this problem, DPMPTSP usually coordinates and clarifies with the Public Works and Settlement Services by calling for a Permit Application on a specific name, where the process goes.

The response from the community is usually satisfied with the DPMPTSP service in order to evaluate community satisfaction with the licensing services provided by DPM PTSP and Naker Pekalongan Regency, a community satisfaction survey was conducted through a questionnaire. Based on the survey results, DPM PTSP and Naker Pekalongan Regency received the table 3 assessments:

Table 3. Community Satisfaction Survey Results

\begin{tabular}{|c|c|c|}
\hline No & Year & Index \\
\hline 1. & 2015 & 72,98 \\
\hline 2. & $2016(1)$ & 74,51 \\
\hline 3. & $2016(2)$ & 72,98 \\
\hline 4. & 2017 & 71,01 \\
\hline 5. & 2018 & 76,62 \\
\hline
\end{tabular}

Source: Dinas DPMPTSP and Naker Pekalongan Regency.

From the results of the community satisfaction survey, it is clear that from year to year, community satisfaction with licensing services has increased, except in 2016 leading to 2017.

So far, the people who take care of the IMB are angry with the services provided, it is not there, it's just that sometimes misunderstandings occur, but with the explanation given by the officer they usually accept it.

If there are updates or new policies that still raise questions, usually the Pekalongan Regency DPMPTSP and Naker Service first ask the Provincial Government.

There are values that are instilled in employees in providing services such as Greet, Smiles, Friendly. As a form of excellent service, when there is an applicant community who still lacks among their requirements, there is usually a call center that will contact him.

In terms of capacity and capability, the staff of the DPMPTSP and Naker Pekalongan Regency employees are generally adequate because they are equipped with the required competencies.

Requirements that are not fulfilled by applicants are rare, but what often happens is generally misunderstanding of these requirements. For example, the requirement is to attach 
proof of PBB payment but usually what is brought is the SPT PBB, because generally what is owned by the community is the SPT.

\section{Conclusion}

Based on the research that has been done, it shows that the performance of the Pekalongan Regency DPMPTSP and Naker Service has shown good performance, it is proven that every year thousands of IMB applications have been completed.

What usually happens is that the community has a misperception of the permits they are taking care of, they think that they have submitted the file to the DPMPTSP Office as a licensing agency in their perception that it is already in order, even though in it there is the Public Works and Spatial Planning Office as well as the Settlement and Environmental Service. Sometimes require certain conditions. This is what sometimes makes it difficult or the process for issuing building permits to be issued takes longer.

The DPMPTSP and Naker Pekalongan Regency Office have tried to instill values in their employees in providing services such as Greeting, Friendly, Smiles. As a form of excellent service, when there are applicants who still have shortcomings among the requirements that must be met, the call center usually follows up so that the applicant immediately completes them.

In terms of capacity and capability, employees are generally sufficient because they are equipped with the required competencies. Requirements that are not fulfilled by applicants are rare, but what often happens is generally misunderstanding of these requirements.

\section{References}

[1] M. Armstrong and A. Baron, Performance management: The new realities. Institute of Personnel and Development London, 1998.

[2] A. A. A. P. Mangkunegara, Manajemen sumber daya manusia perusahaan. PT. Remaja Rosdakarya, 2016.

[3] M. S. P. Hasibuan, Manajemen Sumber Daya Manusia: Pengertian Dasar, Pengertian, dan Masalah. Jakarta: PT. Toko Gunung Agung, 2001.

[4] Y. T. Keban, Enam Dimensi Strategis Administrasi Publik, Konsep, Teori dan Isu. Yogyakarta: Penerbit Gava Media, 2004.

[5] R. S. Schuler, P. J. Dowling, and H. De Cieri, "An integrative framework of strategic international human resource management,” J. Manage., vol. 19, no. 2, pp. 419-459, 1993.

[6] Sudiman, Teknik Penyusunan Organisasi Berkinerja Tinggi. Jakarta: Pusat Kajian Kinerja Kelembagaan LAN, 2004. 